\title{
THE DEVELOPMENT OF SCIENTIFIC PAPER TEACHING MATERIALS USING PROCESS-GENRE APPROACH
}

\author{
Sri Indrawati, Subadiyono, A. Rizki Turama \\ Faculty of Teaching Training and Education, Sriwijaya University Palembang, Indonesia \\ Jalan Masjid Algazali, Bulit Lama, Palembang, South Sumatera, Indonesia \\ Corresponding Author: sri_indrawati@fkip.unsri.ac.id
}

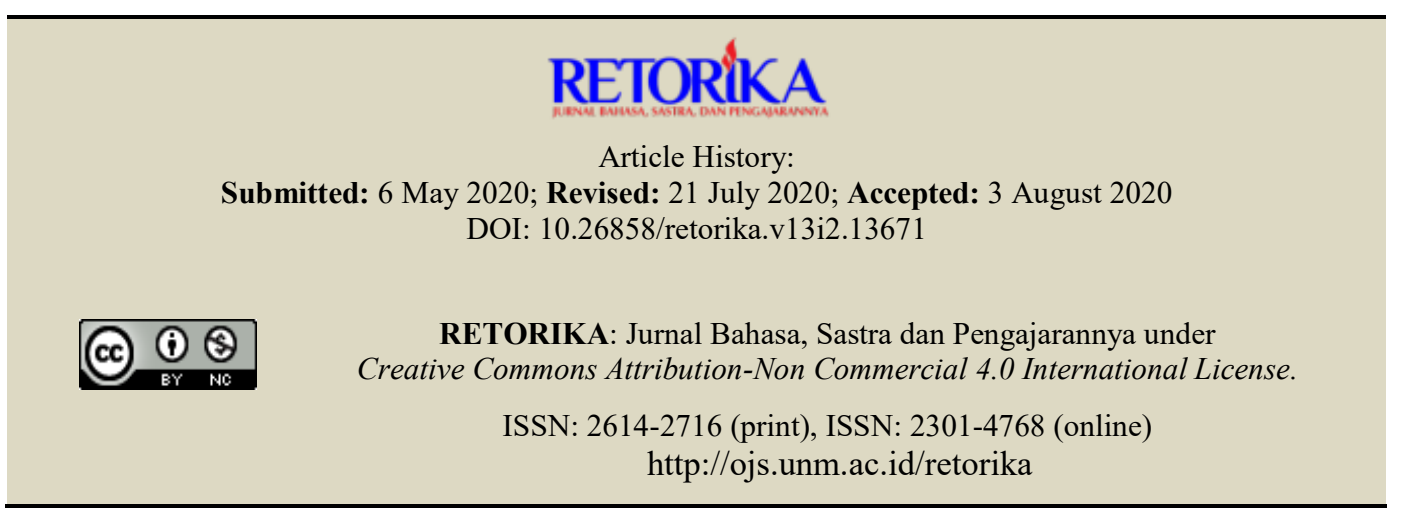

\begin{abstract}
This study aimed to compile materials to teach scientific-paper writing based on needs analysis, expert validation, and practicality test. This study employed a research and development (R\&D) design, of which procedures consisted of needs analysis, prototype development, expert validation, prototype revision, small-group tryout, and product revision. The participants of the study were students from the Indonesian Language and Literature Study Program, FKIP, Sriwijaya University. The data were collected using questionnaires, interviews, and document analysis checklists. The result of the study was a book containing materials to teach scientific-paper writing. The book also contained academic writing concepts and exercises developed based on the Process Genre Approach (modeling, joint construction, individual construction, and writing. The book can be implemented as one of the instructional materials to improve students' academic writing skills.
\end{abstract}

Keywords: development, teaching materials, scientific paper

In the teaching and learning process, there are many factors that affect the success of teaching. They are lecturer, students, teaching materials, evaluation, learning strategies. From these factors, teaching material is one of the factors that influence the success of learning. As stated by Wijaya \& Rohmadi (2009), the success of a learning process is not only influenced by reliable lecturers or teachers, input, learning tools, but the selection of appropriate and effective teaching materials plays an important role.
Some scholars assumed that teaching materials greatly effect learning outcomes. Zakiyah et al. (2012) stated that material developed effectively can be one solution to improve students' writing skills. Teaching materials are materials or subject matter which are arranged coherently and used by educators and students in teaching and learning activities (Sadjati, 2012). In addition, Kristian et al. (2016, p. 211) conclude that well-developed writing teaching materials will overcome the learning gap in schools. Suryaningsih and Kesuma (2018) also suggested 
that well-packaged teaching materials will improve students' writing abilities and improve student motivation.

Good teaching materials have provisions that need attention. A teaching material must have relevance, consistency, and adequacy (Romansyah, 2016: 60). Relevance mean dkks that it is compatible with the curriculum content. Consistency means the stability of the contents of the material. The adequacy of the intent is the completeness of the content. Quality of teaching materials should be based on needs analysis. If there are teaching materials which deviates from the characteristics and needs of students, it will certainly have a negative impact on the learning process in classroom. Therefore, it is necessary to examine the material that has been used in the learning process.

One of materials that aims to guide students to be able to have good academic writing is to write scientific papers. Through scientific work students can pour ideas or thoughts, both the results of their study of a theory and the results of the research they have done. Writing scientific papers can be poured by students on papers, articles, or thesis. In addition, an article is said to be scientific if it meets the applicable criteria.

Some studies state that the scientific work of students is still low. Their writing is still not logical, the the relationship between concepts and substance has not existed yet. Also in analyzing problems and concluding (Supriyadi, 2015 \& Fannier, 2016). One reason is the lack of available teaching materials that are suitable for human needs. Therefore, it is necessary to study the teaching materials that are suitable with the needs of students.

Based on the information obtained from the needs analysis, it found that students had a low understanding of scientific writing. Nearly $86 \%$ of students expressed difficulty in writing scientific papers, articles, and proposals. One reason is the lack of specific teaching material that guides scientific writing (98\%). Therefore, it is necessary to develop teaching materials for writing scientific papers that are appropriate to the characteristics of students.

Development of teaching materials is indeed necessary. Thamrin (2014) assumed that there are three reasons why the development of teaching materials needs to conduct. First, there is still a lack of availability of teaching materials in accordance with curriculum demands. Second, the availability of teaching materials which based on the characteristics of students is still minimum. Third, the inadequate availability of teaching materials based on the demands of solving learning problems.

Scientific work is a written report written about a phenomenon or a scientific activity which is arranged systematically using correct language. A scientific work is compiled based on the results of observations of an event or phenomenon using scientific methods (Munif, 2017). Furthermore, Munif (2017) said that the preparation of scientific works was varied, including activity reports, research reports, books, modules. Thus, in teaching materials for writing scientific papers, there are many things that need to be considered such as the characteristics/ characteristics, types, languages. In creating teaching material, approach is needed. Since teaching materials that use an approach can be more directed, detailed, and interesting. Therefore, research into teaching material development is carried out using an approach, namely the Process Genre Based Approach.

Process Genre Based Approach (PGBA) is one of the learning models that combines writing and text processes. This model has the advantage of combining two approaches, namely genre based approach and process approach genre. This model is quite effective in writing learning. Barger and White (2000) said that the advantage of using the process genre approach is that this approach rewards the flexibility in the writing process. In the process genre approach various writing skills are involved. Mohammed (2016) proposes implementing PGBA in second language writing skills. According to him, PGBA provides usability and strength in the writing process that starts with prewriting, drafting, feedback and revising.

Process Genre Based Approach theory used in this study was a theory combination from Badger and White (2000), Kim and Kim (2005) and Reppen (2002). Badger \& White (2000) and Kim and Kim (2005) put forward the theory of the writing process, namely prewriting, writing, and writing, while Reppen (2002) explains the genre based approach. The development of these two theories has been conducted by Indrawati (2019). The results of the study suggest that the steps of learning PGBA are (1) providing text as modeling, (2) reading and constructing text through discussion, (3) constructing individual texts through 
tasks, (4) carrying out the process of writing through pre-writing activities, writing, and postwriting. The fourth stage component (the writing process) can be done separately from the other three components. However, it can also be applied at stages two and three

The research objective was the creation of teaching materials for writing scientific papers. Teaching materials were in accordance with needs analysis, valid and practical. In addition, this teaching material was expected to be one of the means of reference in improving student writing skills.

\section{METHOD}

This study used research and development method. The study tried to design and make prototype teaching materials with certain specifications. Gall, Gall and Borg (2010) stated that research development models, namely research method used to produce certain products and examine the effectiveness of those products). The steps taken in developing the prototype of teaching materials are as follows. (1) conducting pre-survey to obtain information, through literature reviews, field reviews, interviews. It was used to learn the needs analysis found in the learning of writing scientific papers; Learning of the learning process/ lectures writing scientific papers, consisting of syllabus and SAP, teaching materials, method used, evaluation of learning so that it could be summarized to discuss it. At this stage, the members participated in working on the survey to get a needs analysis. (2) Conducting planning (gathering things which would be developed in the learning process. At this stage, all participants developed discussions using questionnaires and interviews. (3) Developing and compiling prototypes of teaching materials guided by learning models of Genre-Based Learning Processes provided for the need to purchase teaching materials, learning procedures and learning strategies, exercises, assignments, and evaluation tools. (4) Initial testing or expert test or validation was carried out with respondents of experts designing learning models. Three experts battle respondents, 3 experts in the field of Indonesian language learning, they were material, language, and presentation expert. Validation activities were offered to review the initial product, provide input for improvement. The collection of information data was done using a questionnaire. The validity was used to find out validity of the language, material suitability, and presentation. Using sentence language using effective sentences, diction, and punctuation, whether the language used was clear enough not to cause ambiguity. In accordance with the material added to the learning material to write scientific papers through the provision of accurate materials and learning objectives based the curriculum, in accordance with the expected competencies in the lecture syllabus and also needs analysis. Whether the material compiled could be used and applied in lectures to write scientific papers. For obedience, make the order of presentation, lay out, drawings or illustrations, or drawings made or ordered could be of interest and motivate students to learn. (5) Analyzing and revising teaching material products based on input/ suggestions from reviewers. (6) Main field trials were conducted for students and lecturers. There were 6--9 students as respondents. (7) revising the product based on input and suggestions from the results of field trials. This following chart was the method of research.

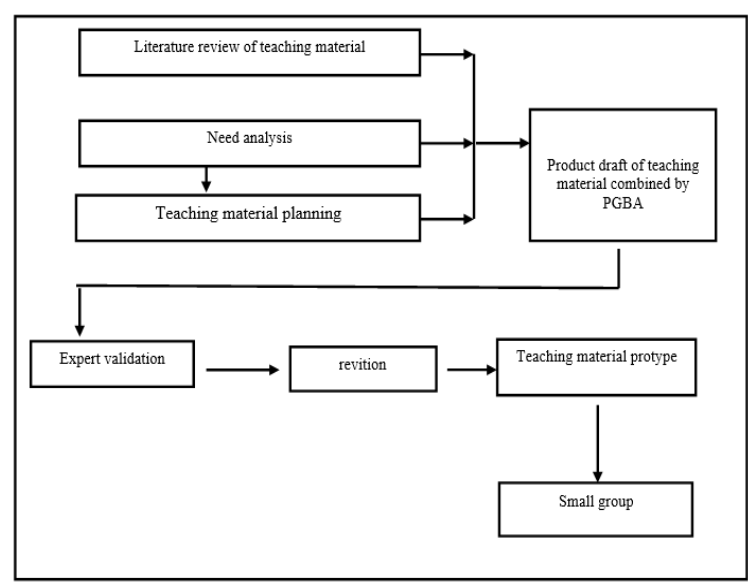

Diagram 1. Research Prosedure

Generally, research and development consisted (1) developing products based on analysis of literature reading needs and responses, analysis of strategies and contexts, selecting materials, (2) revising product development, and (3) using product development.

The subjects of this study consisted of students of the Indonesian Language Study Program, FKIP, Unsri, who took part in the Writing of Scientific Work both from the Inderalaya campus and the Palembang campus. For the needs ana- 
lysis, 50 students of 5 th semester joined this stage. The number of lecturers used as respondents was two people.

Data collection techniques used to gain the data of this study were questionnaires, interviews, assessment sheets, checklists, tests, and observation sheets. First, the survey used questionnaires and interviews. The questionnaire was distributed to students to solicit needs analysis according to their interests, motivations, challenges in learning to write scientific papers. While the questionnaire for lecturers to learn the learning tools used, challenges, and expectations. To get the information needed and verify the data obtained from the questionnaire, interviews were also used. Interviews were conducted with lecturers who taught writing material about the teaching used and hindered it. Second was an assesment sheet. The assessment sheet was used to validate the feasibility of the textbook being developed. Assessment sheets were given to experts to assess aspects of language, understanding of the material deve- loped, and the presentation used. Third was a checklist used to find out the practicality of evaluating teaching material.

This research data wasin the form of qualitative and quantitative data. The research data analysis procedure is as follows. Firstly, analyze data obtained from survey results (needs analysis). Student and lecturer assessment data was obtained by changing the qualitative values into quantitative using a Likert scale on the questionnaire distributed. The feasibility analysis was based on the responses of students and lecturers using the same formula. Calculation to find out the percentage of teaching material needs was done by dividing the average score obtained by the maximum score.

For the analysis of questionnaire and interviews from lecturers only described. It was due to only two lecturers becoming respondents. Categorizing needs was most needed (MN), needed $(\mathrm{N})$, need enough (NE), and less needed (LN) can be seen in the following table 1 .

Table 1. Need Category

\begin{tabular}{ccc}
\hline No. & Persentase Kelayakan & Interpretation \\
\hline 1. & $76-100 \%$ & Most Needed \\
2. & $50-75 \%$ & Needed \\
3. & $26-49 \%$ & Need Enough \\
4. & $<26 \%$ & Less Needed \\
\hline
\end{tabular}

Secondly, make learning designs according to needs analysis. It was identified, analyzed, interpreted, and desinged a teaching material. Thirdly, validating prototypes for experts. The criteria used to learn whether or not good teaching material is if the quality of designing teaching materials is minimally good (value $>3.00$ ). To analyze the results of expert validation obtained from the questionnaire, an assessment sheet was used. Calculation of the average score of each of the criteria collected is sought by referring to the following formula.

Based on the generality of the formula, it can be concluded that the formula for calculating the average score of each aspect and the average score of all aspects. These aspects includeed aspects of content, language, and presentation. After obtaining the percentage value of the feasibility of teaching materials, the categorizes the level of teaching materials based on the interpretation of the scores is presented in table 2 below.

Tabel 2. Score Category

\begin{tabular}{ccc}
\hline Category & Score & Percentage \\
\hline Very Good (VG) & 4 & $4>81,25 \%-100 \%$ \\
Good (G) & 3 & $3>62,5 \%-81,25 \%$ \\
Poor (P) & 2 & $2>43,75 \%-62,5 \%$ \\
Very Poor (VP) & 1 & $1>25 \%-43,75 \%$ \\
\hline & Source: (Widoyoko, 2012: 105$)$
\end{tabular}

Fourthly, revising the prototype according to the experts' advice, if there are still errors. It was identified, analyzed, interpreted, and desing- 
ed a teaching material. Fifthly, testing the revised prototype results to students. The results of the revision of the teaching material were tested on three students who lacked, moderate, and good competence. It was called one-to-one. Subsequently the teaching material was revised and the results were tested on nine students who lacked, moderate, and good competency (small group test). Sixthly, summarizing the results of data analysis. From all steps of study, the teaching material had been developed. The result of the study was a book of scientific writing. It can be used to improve students' academic writing skills.

\section{Findings}

Based on the results of the questionnaire data analysis, student needs can be identified. Analysis of student needs was grouped into six parts, namely (1) the need for teaching material to write scientific papers in classrrom, (2) the types of scientific paper needed, (3) the structure of the desired scientific work, (4) the material topics in writing scientific paper, (5) learning approaches, (6) presentation of material in books. For more details the results of the analysis of teaching material requirements can be seen in the following table 3.

\section{FINDINGS AND DISCUSSION}

Tabel 3. The Needs of Teaching Material

\begin{tabular}{clcc}
\hline No. & \multicolumn{1}{c}{ Aspect } & Percentage & Category \\
\hline 1. & Teaching material for writing scientific papers & 82 & Most needed \\
2. & Types of scientific papers & 65 & Needed \\
3. & Structures of scientific papers & 85 & Most needed \\
4. & Topiics of scientific papers & 80 & Most needed \\
5. & Learning approach & 75 & Needed \\
6. & Material presentation & 76 & Most needed \\
\hline
\end{tabular}

Based on the above table, it showed that the need for scientific writing material was very necessary $(82 \%)$. In terms of scientific papers, respondents need forms of scientific papers in the form of papers, articles, proposals, and theses $(65 \%)$. The structure of scientific papers which were needed by the respondents includes an introduction, literature review, methods, discussion, and conclusion (85\%). The most desirable topic of writing material was the concept of scientific paper, the characteristics of scientific paper, writing techniques, bibliography, and examples (80\%). Respondents really desired the Process Genre Based Approach were used in the preparation of teaching materials (75\%). Respondents really needed the presentation of teaching materials written in a coherent, complete, and standard language $(76 \%)$.

\section{Prototype of Teaching Materials Writing Sci- entific Papers}

From the results of the needs analysis, teaching materials for writing scientific papers were formed in the form of book. The book consisted of seven chapters. Chapter 1 contained the concept of scientific work covering the understanding and characteristics and the purpose of writing scientific paper. Chapter 2 contained the principles of writing scientific papers. Chapter 3 contained the types of scientific work (papers, articles, final project, thesis, thesis, dissertation, proposal, research report, and scientific oration). Chapter 4 contained guidelines for writing scientific papers (articles of research results and conceptual articles). Chapter 5 consisted of proposal writing techniques (systematic proposal, background, literature review, and research methods). Chapter 6 included thesis writing techniques (systematic, introduction, literature review, research methods, results and discussion, conclusions and suggestions). Chapter 7 consisted techniques for writing bibliography (quotations and references).

The teaching material was followed by illustrations, examples, and exercises. In addition, teaching materials for writing scientific papers which were developed were written with reference to the Process Based Approach Genre approach. In other words, the teaching material was written by referring to the steps of learning Process Genre Based Approach. Firstly, model pre- 
senting. The model was in the form of text samples. The text displayed was based on the submission of scientific writing. Students were asked to read, observe, and study the text. The second was joint construction. In this sectio, the students discussed the exemplary text (e.g essays). The topics were the procedures for composing essays, sentences, and vocabulary. Third was individual construction. In individual construction, the students practiced analyzing texts individually. In this section students practiced compiling a text, designing topics, making procedures/ stages of writing a particular text. Fourth was the writing process. In this section, the students were asked to write ideas, opinions, ideas related to the text. This writing process could be poured by students into essays in the form of one or more paragraphs, essays. or article. In the process of writing several components of the writing process activities such as pre-writing, writing, and post-writing were used. This teaching material was also presented in a coherent, complete, detailed, and communicative language.

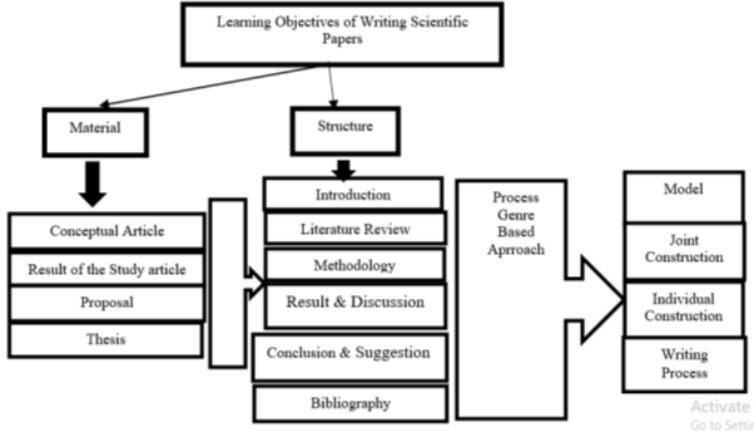

Digram 2. Prototype Chart of Teaching Materials Writing Scientific Papers

\section{Expert Validation}

The prototype of teaching material which had been prepared and developed was validated by three experts, namely language validator, substance validator or content, and agreement validator. The results of the validation of the three validators can be seen in the following table 4 .

Table 4. The Result of Expert Validation toward Teaching Material Prototype

\begin{tabular}{cccc}
\hline No. & Aspect & Percentage & Category \\
\hline 1. & Language & 96,87 & Very Good \\
2. & Material & 95,31 & Very Good \\
3. & Presentation & 95 & Very Good \\
\hline & Means & 95.72 & Very Good \\
\hline
\end{tabular}

From the above table, it can be concluded that the results of the validation of linguists, material experts, and presentation experts on the prototype of teaching materials for writing scientific papers are very good. In terms of language worthiness, namely language standardization, readability of sentences, conformity with the level of intellectual development, and the wrangling and integration between sentences and paragraphs was classified as very good $(96.87 \%)$. Of the feasibility or content, which included the suitability of the material with the achievement of learning, accuracy, finesse, and suitability with the development of KKNI (Indonesian National Curriculum Competency) was classified as very good (95.31\%).

Although the results of the validation analysis were very good, there were a number of sug- gestions given by the validator. The language validator's suggested that some non-referential words which were still lacking in operational use need to be revised. The material validator proposed that it was very necessary to add examples. The presentation validator's recommended that the letters in the sample letters need to be enlarged. All suggestions had been corrected.

\section{The Result of Small Group Tryout}

The prototype of the revised teaching material based on the results of the validator was tested for practicality on nine students who had poor, moderate, and good abilities. This practicality test covered aspects of material clarity, language, attractiveness, and appearance. Following table 5 are the results of practicality analysis on the small group test. 
Table 5. Average Practical Component Score

\begin{tabular}{cccc}
\hline No. & Validation Aspects & Percentage & Category \\
\hline 1 & Material Clarity & 88,88 & Very Good \\
2 & Language Use & 98 & Very Good \\
3 & Enchancment & 88 & Very Good \\
4 & Layout & 85 & Very Good \\
\hline & Means & 89.97 & Very Good \\
\hline
\end{tabular}

From the table above, it can be seen that the practicality components of clarity, language, attractiveness and appearance were generally very good $(89.97 \%)$. Judging from the clarity of the material which included sufficiently detailed material, the description from easy to difficult, according to the learning objectives, in accord-ance with learning outcomes, content completness, clear questions and instructions obtained an average of $88.88 \%$ (very good).

In terms of language aspects including effective sentences and easy to understand, vocabulary and terms easy to understand, and standard Indonesian spelling obtained 98\% (very good). In terms of attractiveness aspects consist-ing teaching materials for writing scientific papers encouraging/ motivating to learn to write scientific essays, examples, illustrations and charts which facilitated learning to write scientific papers, and teaching materials for writing scientific papers were very useful in adding insight in the field of writing obtained $88 \%$ ( very good).

Judging from the aspect of the display which included illustrations/ examples which were displayed it is easy to understand the material, fonts in teaching materials were easy to read, teaching materials increased learning motivation, and information in complete teaching materials was obtained by an average of $85 \%$ (very good).

\section{Discussion}

Based on the questionnaire $82 \%$ of the students believed that this teaching material was important. It showed that teaching material for writing scientific paper was very needed by the students. Several research studies have discussed the study of writing scientific papers in learning, among others, Singh \& Mayer (2014, Novales et al. (2014), Abdukhakimova \& Yingqiu Xie (2020). Their findings reveal that writing scientific papers was very necessary for students. Writing scientific papers had a positive influence on the ability to reason and think critically, scientific works are able to train to write ideas systematically and logically.

The result showed that the teaching material created has fulfilled the needs analysis. Teaching material for writing scientific papers was already valid and practical. As stated by Sultan (2015), Mustafa \& Efendi (2016), Rediati (2015), Pertiwi et al. (2016), and Arsanti (2018) teaching materials were effective if they had been tested for validity and practicality. Valid teaching materials were teaching materials both in terms of content, language, and presentation. Practical teaching material means teaching material which was easy to use and understand.

The distribution of scores $(88 \%)$ in the practical test showed that the developed teaching material could motivate students to write their work. Thus, the teaching material which had been produced had several advantages, such as: teaching material contained material for writing scientific papers which includes concepts, types, and structure of scientific works. Material writing scientific papers was packaged using a process genre based approach. Teaching material from each unit was packaged by using PGBA. This means that the material from each unit is packaged through modeling, joint construction, individual construction, and writing processes (prewriting, drafting, and post-writing).

The creation of teaching materials for writing scientific papers based on PGBA provided advantages in the learning process. This is due to the fact that the learning procedures which had been packaged in the material need to be done by students in accordance with the activities at PGBA. Provision of text modeling in the initial activity could provide input knowledge about the text and its context. The understanding of the text and its context continued with the joint construction. In this activity, students discusse the text being read. Furthermore, independent construction, in this activity students were directed to examine the acquisition of joint construction by concluding the text. In the final activity, the 
writing process, the activity carried out wasstudents writing a text with the steps of prewriting, drafting, feedback and revision.

Several advantages of PGBA study results in writing skills had been revealed by several experts. Ueasiripan \& Tanklengsirisin (2019) examined the approach of genre-based writing to technical writing skills to Thai engineers. The genre based writing approach refers to the following procedures: building the context, modeling and deconstructing the text, joint construction of the tex, independent construction of the text, and, linking related texts. The results of the study showed that the writing skills of the engineers increased. In other words, genre based writing approach had an effect to writing skill.

Furthermore, Burgo (2016) examined genre based approach to the ability to write expository texts, Rusinovci (2015), Dirgeyasa (2016), Xiwen Xu (2018), Samsudin \& Arif (2018) and Nagao (2019) reviewing genre basd approach (GBA) on academic writing skills. Burgo (2016) research results concluded that there is an influence of genre based aprooach (GBA) on expository writing skill. The procedures performed in the GBA were the deconstruction stage, joint construction stage, and individual construction stage. Rusinovci's research findings (2015), Dirgeyasa (2015), Samsudin \& Arif (2018), and Nagao (2019) concluded that there was an influence of GBA on the ability of academic menuls. The procedures performed were modeling, joint construction, and individual constrution.

Although PGBA had advantage that the writing process was done more specifically, there were also some weaknesses. The stages of the writing process in the last activity had an impact on the implementation of learning. The availability of time was long enough to use PGBA. At school it was not possible just enough for 1 meeting ( $2 \times 45$ minutes). In addition, the selection of materials was for contextual texts.

The results of this research had theoretical and practical implications. The theoretical results of the research were expected to be able to imply the contribution of specific theories of genre theory, which was launched by several experts, such as Bardger and White (2000), Hyland (2003). Practically the results of research could be implicated in language learning. This was due in the 2013 curriculum at the junior and senior high school levels, specifically for language learning all text-based teaching material (genre). Thus, the PGBA approach was expected to be carried out because it was in line with the genre (text-based) approach. In addition, writing skills were not only limited to writing excitation, argumentation but broad academic writing skills. In addition, PGBA could also be applied in other language skills, such as speaking.

\section{CONCLUSION}

From the results of data analysis, it can be concluded that the analysis of the need for teaching materials for writing scientific papers was very essential. Teaching materials desired by students were teaching materials for writing a complete work containing the concepts of writing a scientific work as well as concrete examples. This was due to students having difficulty in writing scientific papers.

Teaching material for writing scientific papers had been formed based on needs analysis. The prototype of teaching material for writing scientific papers had been created with components: concepts of scientific work, principles of writing scientific papers, types of scientific works, guidelines for writing scientific papers, proposal writing techniques, thesis writing techniques, citation writing and bibliography, references, glossaries, and index.

The results of the validation of the textbook for Teknik Penulisan Karya Ilmiah were very feasible to use. Based on the results of validation by experts, both the language, substance, and presentation of the book have met the criteria of a good book. The result showed that the scores obtained already showing the expected criteria. Thus, this textbook was quite optimal.

From the results of the practicality test, the book Teknik Penulisan Karya Ilmiah based on the opinion of students of the book was very practical. Practicality could be seen from the aspects of language, material, attractiveness, and appearance or presentation. From the aspect of language, sentences and vocabular/ terms used are standard and easy to understand. From the material aspect, the information contained in the complete and detailed book, the material was arranged systematically. From the aspect of attractiveness, this textbook contained examples or illustrations that encourage learning and add insight. From the aspect of appearance (lay out), 
the font was quite good, illustrated, the chart was neatly packaged so that it motivated to read the book. This research had not accomodated all components in the development research method One of them was the effectiveness test. Therefore, the research needed to be continued by testing it in the field using the moodle application.

From the results of data analysis, it can be concluded that the teaching material which had been developed, had conformity to the needs, it contained the concepts of writing a scientific work as well as concrete examples. Teaching material which had been packaged in such a way gave a positive attitude in writing scientific work. In addition, this teaching material could be a solution in improving students' scientific writing skills.

Teaching material for writing scientific papers had also been tested for validity and practicality. Thus, the teaching material had met the criteria of a good teaching material. So, writing scientific material could already be used in the learning process at school. Teaching material developed had a characteristic which teaching material was prepared by referring to the PGBA approach. In other words, every teaching

\section{REFERENCES}

Abdukhakimova, D. \& Yingqiu Xie. (2020). Supervising Students in Scientific Writing for Peer Review \& Possible Publication. The American Biology Teacher, 82 (3): 158-161.

Arikunto, S. (2014). Prosedur Penelitian Suatu Pendekatan Praktik. Jakarta: Rineka Cipta.

Arsanti, M. (2018). Development of Creative Writing Subjects with Character Education Values. Jurnal Kredo, 1(1): 71-85.

Badger, R., \& White, G. (2000). Product, Process and Genre: Approaches to Writing in EAP [Electronic version]. ELT Journal, 54(2): 153-160.

Gall, M.D, Gall, J. \& Borg, W. (2010). Educational Research: An Introduction. New York: USA.

Dirgeyasa, I. Wy. (2016). Genre-based Approach: what and how to teach and to learn writing. English Language Teaching, 9(9): 45-51.

Hyland, K. (2003). Genre-Based Pedagogies: A Social Response to Process. Journal of Second Language Writing, 12: 17-29.

Indrawati, S., Subadiyono \& Turama, A.R. (2019). Academic Writing Based on Process Model Genre Based Approach. Palembang: Noerfikri.

Indrawati, S. \& Subadiyono. (2018). Process Genre Based Approach Model in Learning. Academic material was packed in the modeling, joint construction, individual construction, and writing process. This was what distinguishes it from other arpproach-based genre models.

As a teaching material, teaching material writing scientific papers had advantages and disadvantages. As an advantage, this teaching material already had complete materials, both concepts and skills. The teaching material was equipped with text modeling, discussion, independent assignments. However, this teaching material also had weaknesses. The weakness was the time allocation in implementing it. In addition, it iwas necessary to choose teaching materials which were truly contextual, as well as the activeness and seriousness of students and teachers.

This teaching material had not been tested for effectiveness. Since not all of components in the research development were conducted yet. One of them wasa field test. Therefore, teaching materials for writing imiah works needed to be followed up by trying them out in the field using technology applications, such as moodle, google classroom, webex.

Writing Skills. Journal International Seminar and Annual Meeting BKS-PTN Wilayah Barat, 1(1): 658-662. Online. Accessed March 25, 2019 from http://conference.unsri.ac.id/index. $\mathrm{php} / \mathrm{semirata} /$ index

Kim, Y., \& Kim, J. (2005). Teaching Korean University Writing Class: Balancing the Process and the Genre Approach [Electronic Version]. Asian EFL Journal, 7(2): 1- 15.

Kristian, N., Suyono \& Sunaryo. (2016). Development of Teaching Materials Writing Research Reports Based on Reading Schemata Enrichment. Jurnal Pendidikan: Teori, Penelitian, dan Pengembangan, 1(2):203-213.

Mohammad, S. M.N. (2017). The Best Of Two Approaches: Process/ Genre Based Approach To Teaching Writing. The English Teacher, Vol. XXXV: $75-85$.

Mustafa, D.A.I. \& Efendi, A. (2016). Development of Learning Teaching Material for Writing Story Based Process Approach for Middle School Students. Ling Tera. 3(1): 1-8.

Munif, A. (2017). Writing Scientific Papers. Accessed, 12 March 2018 from https://www.research gate.net/publication. 
Novales, C. I. P., Padron, N. Q., Murguia, A. P., \& Rivero, P. L., G. Hondares, L. E.M. (2014). Aspectos Importantes de la Redaccion Cientifica (Important aspects of scientific writing). Rev Ciencias Medicas, 18(2): 362-380.

Nagao, A. (2019). A Genre Based Approach to Writing Instruction in EFL Classroom Context. English Language Teaching, 11(5):130-147.

Prastowo, A. (2012). Creative Guide to Making Innovative Teaching Materials. Yogyakarta: Diva.

Rediati, A.(2015). Development of an Enrichment Text Book with Local Cultural Values for Elementary Schools. Seloka: Jurnal Pendidikan Bahasa dan Sastra Indonesia, 1:1-7.

Rusinovci, X. (2015). Teaching Writing through Process-Genre Based Approach. Online. Volume 5 Number 10. Accessed April 13, 2018 from http://www.davidpublisher.org/public/uploads /Contribute.

Rormansyah, K. (2016). Guidelines and Presentation of Indonesian Language Teaching Materials. Jurnal Logika, 27(2):59-66

Sadjati, I.M. (2012). Development of Teaching Materials. Jakarta: Universitas Terbuka. Sarmadan. 2017. Development of Teaching Materials Writing Scientific Papers in Teaching Indonesian at STIKOM Jambi. Jurnal Ilmiah Universitas batang Hari Jambi, 17(1):159-171.

Samsudin, Z. \& Arif, M.F. (2018). The Efficacy of the Genre-Based Approach in Teaching Academic Writing. International Journal of Management and Applied Science, 4(6):90-97.

Singh, V., \& Mayer, P. (2014). Scientific Writing: Strategies and Tools for Students and Advisors. Biochemistry and Molecular Biology Education, 405-413.
Saleh, M. \& Sultan. (2015). Pengembangan Materi Ajar Berbasis Kurikulum 2013yang Mengintegrasikan Nilai Karakter di SMP. Jurnal Pendidikan dan Pengajaran, 2 (22):117-129.

Supriyadi. (2015). Development of Writing Learning for Scientific Work with Constructivism Approach. Litera, 14(2): 361-375.

Suryaningsih, N. \& Kusmana, S. (2018). Development of Teaching Materials Writing Scientific Papers Based on Constructivism Approaches. Jurnal Tuturan, 7(2):884-894.

Thamrin, M. (2014). Development of Learning Materials for Writing Vocational Based Scientific Papers. Jurnal LITERA, 13 (1): 90-101.

Ueasiriphan, T \& Tangkiengsirisin, S. (2019). The Effects of Genre-Based Teaching on Enhancement of Thai Engineers' Technical Writing Ability. International Journal of Instruction, 2(12): 723-738.

Wijaya, P.D. \& Rohmadi, M. (2009). Pragmatic Discourse Analysis: Theory Study and Analysis. Surakarta: Yuma Pressindo.

Widoyoko. E. P. (2012). Research Instrument Designing Techniques. Yogyakarta: Pustaka Pelajar.

Xiwen Xu. (2018). Teaching Academic Writing through Process Genre Approach: A Pedagocical Explrotion on EAP Program in China. TESL-EJ, 22(2):1-21.

Zakiyah, M., Suyono, \& Roekhan. (2012). Development of Critical Thinking Education Teaching Materials through Learning Writing Scientific Papers in SMA/MA. Accessed April 14, 2019 from https://jurnal-online.um.ac.id/data/artikel. 